\title{
Consolidation of democracy and historical legacies: a case study of Taiwan
}

\author{
Christian Schafferer*
}

In political science there is broad interest in whether a newly established democracy succeeds in overcoming the perils of democratisation and matures into a consolidated democracy or regresses to authoritarianism. Taiwan was under martial law for almost four decades. Democratic consolidation, therefore, is primarily a question of how to overcome the legacies of the former authoritarian regime. Nationalism and dysfunctional political institutions are some of the legacies that limit Taiwan's democratic development. The study of these destructive elements is important in the attempt to interpret Taiwan's most recent political history and to formulate effective democracy-building policies. In the following, I would like to address the aforementioned legacies and their implications for Taiwan's current and future democratic development.

\section{Dimensions of democratic consolidation in Taiwan}

In the late twentieth century, political scientists around the world focussed their attention on the third occurrence of a global wave of democratisation in modern history (Huntington 1991). The Wave toppled authoritarian regimes in all parts of the world. Political analysts welcomed the new development and concluded that liberal democracy had finally prevailed over all other forms of political governance (Fukuyama 1992). However, a number of political 'crises' in newly established democracies over the last few years and the humanitarian consequences of the USlead 'War on Terror' brought an end to this global euphoria and political analysts subsequently predicted a global resurgence of authoritarianism (Diamond 2008, Quimpo 2008).

In advanced democracies, the recent discourse on the contemporary crisis of democratic development has mainly focussed on the 'War of Terror', its humanitarian consequences and the justification thereof. The Asian discourse, on the other hand, has tried to answer the question of whether democracy has failed in Asia and whether it is appropriate for Asian societies to adopt Western democratic values and institutions (Thompson 2008). As a matter of fact, all newly established democracies in Asia have experienced some sort of political unrest in recent years. In each case, however, the political turmoil has been the result of neglected historical legacies rather than cultural barriers. Taiwan is no exception. Taiwan's political development has given rise to a number of socio-political confrontations and 'crises' since the early stages of its democratic development. I believe that these "crises" have predominately been the result of historical legacies. Taiwan's current and future democratic development depends on the society's ability to overcome these legacies. In this paper, I assert that three different types of historical legacies that constitute three dimensions of democratic consolidation in Taiwan. Ethnic and national identity constitute the first

\footnotetext{
* Associate Professor, Department of International Trade, Overseas Chinese University, e-mail: chris@ocu.edu.tw
} 
dimension. The second dimension comprises institutions, such as parliament, the judiciary and media, and institutionalised processes, such as education, that were used during authoritarian rule to control society and have not yet adapted themselves to the new, democratic environment. The third dimension has to do with the authoritarian mindset that still exists in elitist political circles and the authoritarian concept of turning politics into popular culture. In the following, I would like to elaborate on these three dimensions and how they have affected Taiwan's democratic development.

\subsection{Han nationalism, Taiwanese nationalism and transitional justice}

During World War II, the United States reached an agreement with President Chiang Kai-shek providing that Taiwan would eventually be returned to China. Soon after the war, Chiang Kai-shek appointed a committee headed by Chen Yi to take over the island's administration. The Taiwanese could not, however, identify with the new government and considered it a foreign regime that had come to Taiwan to "loot" the island (Peng 1972, 61). The Chinese nationalist (KMT) government under Chiang Kaishek and later his son Chiang Ching-kuo promoted Han nationalism with the aim of eventual "liberalization" of the Mainland. The future Han nation would consist of "one state, one people, [and] one language" (Windrow 2005, 412). As part of this attempt, the KMT government was determined to assimilate the native population of Taiwan through social control and education. The Han-nation building process severely affected the daily lives of the native population. Regulations forbade the use of Japanese, aboriginal and Sinitic languages other than Mandarin. Ethnic origin and the ability to speak Mandarin worked as keys to power and became instruments of social control. The KMT government purged state institutions of the local people, the Taiwanese, and within a few years the Mainlanders, the ethnic minority, held the majority of key positions in government and state-run industries (Chen 2006, 110).

The Han nationalists justified the purges with the claim that the "primitive prostitute culture" of the "local population" lacked the ability to govern the island (Windrow 2005, 411).

Social and political injustices caused by the Han-nationalists' dogma of racial superiority and widespread bureaucratic inefficiency led to the 228 Massacre of 1947, in which Chiang Kai-shek's troops brutally killed thousands of Taiwanese. Two years later, the Han nationalists lost the Civil War on the mainland and retreated to Taiwan. Martial law was imposed the same year and remained in effect until 1987. The defeat on the mainland and Mao Ze-dong's subsequent proclamation of the People's Republic of China, the de-facto and de-jure successor state of the KMT's Republic of China, caused a crisis of legitimacy for the Chiang Kai-shek regime. On the international stage, the USA assisted Chiang Kai-shek in maintaining the myth that the KMT government was the sole legitimate government of China (Lin 1986). Domestically, the myth was kept alive by promoting Han nationalism and persecuting any opponent thereof. The KMT regime under Chiang Kai-shek and his son Chiang Ching-guo set up a network of informants to monitor the political and social activities of co-workers, neighbours and even family members at home as well as abroad. Secret police units, interrogation centres, political prison camps and execution grounds existed throughout the island. Torture and (extra-judicial) executions were widespread and systematic until the late 1970s. The total number of victims is difficult to gauge, since a large number of executions were extra-judicial and thus mostly without any records. According to declassified information, the majority of extra-judicial executions were carried out in the 1950s, when about 130,000 people 
were reported missing. ${ }^{1}$ As of today, there are over ten thousand well-documented cases of gross human rights violations committed by the KMT regime. ${ }^{2}$

Although the issue of transitional justice has been neglected by foreign academia, it has shaped Taiwan's political landscape and emerged as one of the major obstacles to further democratic development. Since the lifting of martial law in 1987, there have been several different approaches as to how to deal with the atrocities. The first attempt to address the past occurred during Lee Teng-hui's presidency. Lee Teng-hui, a native of Taiwan, succeeded Chiang Ching-kuo after his death in 1988. Lee had a close relationship with the former dictator, whom he considered his political mentor. In his later writings, he notes that his succession was an accident caused by historical circumstances rather than being the result of Chiang's personal wishes (Lee 2004, 810). Lee's assessment based on the fact that he was neither a mainlander nor a staunch supporter of Han nationalism. Many senior party figures were well aware of Lee's political leaning towards Taiwanese nationalism and they made several unsuccessful attempts to oust Lee from the party leadership and the presidency (Zhou 1993; Lin 2004).

The immediate post-martial-law years saw a number of large-scale protests demanding several groundbreaking political and social reforms. Although human rights activists and victims of the KMT atrocities called for transitional justice, President Lee started his term in office with a press conference merely stating that the people of Taiwan "should not dig in the past." Lee's long-term career in the repressive regime and his close friendship with the former dictator might have been the key factors behind his refusal to address the past. With the conflict between Lee and the conservative wing intensifying, Lee saw in public support the key to his political survival, and he therefore increasingly presented himself as a statesman who would "listen to the hearts of the people." As to the issue of transitional justice, Lee had to readjust his policies in such a way that he would neither neglect public opinion nor endanger his political career as party leader and president. Lee thus publicly apologized for the 2-28 Massacre and initiated a set of laws that would allow victims to get financial compensation for the past wrongs of the Nationalist government, but fell short of supporting any initiative that would encourage people to question the role of the KMT and its leaders in the atrocities.

His successor had a rather different approach. Chen Shui-bian was the first president of Republican China who was not a member of the Chinese Nationalist Party (KMT). During the martial law era (1949-1987), he was a key participant in the opposition movement. The international community thus praised Chen Shui-bian's victory in the presidential election of March 2000 as a major step forward in Taiwan's process of democratisation. As a former human rights lawyer, Chen put great emphasis on improving the democratic environment. A large number of his democracy-consolidating policies were related to transitional justice. The aims of his government policies were to separate the State from the KMT, to make people aware of the wrongfulness of the atrocities committed during the martial law era, to find ways of reconciliation, and to set preventive measures. However, during his two terms, the DPP government could only partially succeed in addressing the issue of transitional justice by (see also Table 1):

- Establishing a commission to investigate responsibility for the 2-28 Massacre

- Drafting laws and holding a referendum on the return of KMT martial law assets to the State 
- Renaming Chiang Kai-shek International Airport and Chiang Kai-shek Memorial

- Removing Chiang Kai-shek statues

- Closing Chiang Kai-shek and Chiang Ching-kuo's mausoleums

- Rehabilitating victims' reputations

- Declassifying government documents related to human rights violations

Chen's transitional justice initiatives as well as other measures designed to improve human rights standards encountered several constitutional and societal obstacles. As to the first, the constitution vests very limited power in the president and thus a president lacks means to push through legislation in a parliament where his or her party does not enjoy a majority of seats. Throughout Chen's presidency, the Han nationalists had a clear majority in parliament. Any piece of legislation thus needed their support, which was unlikely primarily for two reasons. First, as pointed out earlier, the major obstacle of Taiwan's democratic consolidation is the KMT legacies. However, removing the KMT legacies inevitably creates clashes with the KMT and its staunch supporters. Second, Taiwan is confronted with an unfortunate and possibly unique linkage between transitional justice and national identity. Since the lifting of martial law in 1987, demands for transitional justice has mainly come from supporters of Taiwanese nationalism and resistance to it from Han nationalists. Both groups question the other's understanding of transitional justice and harbour different views on three important historical events (see Table 2), namely the 2-28 Massacre, the White Terror and Japanese aggression during World War II.

As to the 2-28 Massacre, the Han nationalists do not deny its existence but persistently claim that it was caused by "language barriers" and "some corrupt local government officials." Thus, neither the KMT nor Chiang Kai-shek could be held responsible for the massacre. As to the atrocities committed during the White Terror, key supporters of Han nationalism have either kept silent on the issue or justified the offences by claiming that they were

"in accordance with the law and necessary as to protect Taiwan from Communist infiltration. I don't understand what all the fuss is about? They [Taiwanese] should be grateful to Chiang Kai-shek and his son for protecting Taiwan against the Communists and for turning Taiwan into an economic miracle." 3

Chiang Kai-shek and his son Chiang Ching-kuo are therefore considered by the Han to be heroic leaders who deserve a special place in world history. Every year, thousands of Han nationalists (including the top leadership of the KMT) march to the former dictators' mausoleums to pay homage. Such deification amplifies their conviction that the two dictators' mausoleums and other places commemorating the two dictators" "achievements" should be protected by the State. Moreover, Han nationalists tend to consider any attempt to close, remove, or rename those historic sites as an act of treason. 
Table 1: Transitional Justice Initiatives in Taiwan (1988-2008)

\begin{tabular}{|c|c|c|}
\hline & 1988-2000 & 2000-2008 \\
\hline President & Lee Teng-hui (KMT) & Chen Shui-bian (DPP) \\
\hline $\begin{array}{l}\text { Legislative } \\
\text { majority }\end{array}$ & KMT & KMT and allies \\
\hline $\begin{array}{l}\text { Scope of } \\
\text { initiatives }\end{array}$ & limited & limited \\
\hline Barriers & $\begin{array}{l}\text { - Lee's close relationship to for- } \\
\text { mer dictator Chiang Ching-kuo, } \\
\text { his own long career in the re- } \\
\text { pressive regime, and his per- } \\
\text { sonal opinion that there is no } \\
\text { need in a democratic society to } \\
\text { talk about the past. } \\
\text { - Media and mainstream dis- } \\
\text { course dominated by Han na- } \\
\text { tionalists. }\end{array}$ & $\begin{array}{l}\text { - DPP short of majority in par- } \\
\text { liament } \\
\text { - Media and mainstream dis- } \\
\text { course dominated by Han na- } \\
\text { tionalists } \\
\text { - Highlighted allegations of cor- } \\
\text { ruption and poor leadership } \\
\text { - Chen's ambivalence toward Ja- } \\
\text { panese revisionism } \\
\text { - National identity conflict } \\
\text { - Foreign support for Han nation- } \\
\text { alists because of pressure from } \\
\text { China and lack of interest }\end{array}$ \\
\hline
\end{tabular}

\begin{tabular}{|c|c|c|}
\hline $\begin{array}{l}\text { Actions } \\
\text { taken }\end{array}$ & $\begin{array}{l}\text { - Set up commission to investi- } \\
\text { gate the 2-28 Massacre and pro- } \\
\text { pose suggestions on how the } \\
\text { government should deal with it } \\
\text { - Public apology for the } 2-28 \\
\text { Massacre } \\
\text { - Compensation of victims }\end{array}$ & $\begin{array}{l}\text { - Set up commission to investi- } \\
\text { gate the responsibility of the 2- } \\
28 \text { Massacre } \\
\text { - Drafting of laws and holding of } \\
\text { a referendum on the return of } \\
\text { KMT martial law assets to the } \\
\text { state. } \\
\text { - Renaming of Chiang Kai-shek } \\
\text { International Airport and } \\
\text { Chiang Kai-shek Memorial } \\
\text { - Removal of Chiang Kai-shek } \\
\text { statues } \\
\text { - Closure of Chiangs' mausole- } \\
\text { ums } \\
\text { - Rehabilitation of victims' repu- } \\
\text { tation } \\
\text { - Declassification of government } \\
\text { archives }\end{array}$ \\
\hline
\end{tabular}


Table 2: Perceptions of human rights abuses in Taiwan

Han nationalists

\begin{tabular}{ll}
\hline Political wing & $\begin{array}{l}\text { Chinese Nationalist Party } \\
\text { (Kuomintang, KMT), People First } \\
\text { Party, New Party }\end{array}$
\end{tabular}

2-28 Massacre Acknowledge existence of the massacre, but persistently deny responsibility: Neither the KMT nor Chiang Kai-shek was responsible for the Massacre. It merely was the result of some corrupt local (Taiwanese)

officials and language barriers.

White Terror Avoid any discussion about it. There mostly is neither denial nor acknowledgment of the systematic and widespread human rights abuses. There is however a great deal of justification and belittlement:

- The White Terror was necessary as to - There is no justification for the protect Taiwan from Communist infiltration.

- Only a few communists were killed.

- Taiwanese should be grateful to the KMT and its leaders for protecting Taiwan and turning Taiwan into an economic miracle.
Taiwanese nationalists

Democratic Progressive Party (DPP), Taiwan Solidarity Union, Taiwan Independence Party ${ }^{1}$

Chiang Kai-shek was the prime culprit of the Massacre. KMT was a foreign regime that came to Taiwan to loot the island.

- KMT leadership should take full responsibility for the atrocities.

- Victims should be compensated using the KMT's party funds.

- The KMT's party archives should be confiscated and made accessible to the victims. atrocities. The statement "no KMT, no economic miracle" is racist and discriminates against the Taiwanese.

- Chiang Kai-shek, his son and the KMT state abused their authority to satisfy their own personal demands rather than merely applying necessary measures to protect Taiwan from the Communists.
Chiang Kaishek and Chiang Chingkuo
- Men of noble character. According to - They were both dictators. the current KMT party charter, Chiang - It is immoral and irreconcilable with Kai-shek still is the Director-General of democratic principles to commemorate the party.

- Chiangs' mausoleums and other places commemorating the "greed deeds" of the two "heroic" Chinese leaders should be protected by the state. Their closure and the renaming of places commemorating them are acts of treason.

Attitude toward - Hostile attitude as result of Japanese Japanese revisionism dictators. Statues, mausoleums, and other places commemorating the Chiangs must therefore be removed, closed or renamed. aggression during World War Two. - Demand apology and compensation for the Rape of Nanjing and other atrocities committed by the Japanese during the War
- Friendly attitude toward Japan: A large number of influential figures in the Taiwanese nationalist movement were educated in Japan and have close ties to right-wing intellectuals.

- Ambiguous position toward Japanese aggression.

Source: Author's own research

${ }^{1}$ The party de-facto ceased to exist in 2002. 
The Taiwanese nationalists disagree with such interpretations of these two tragic events and the positive appraisal of the Chiang family. In their view, the KMT, Chiang Kai-shek, and his son were brutal dictators and therefore do not deserve special status in a modern democratic state. The removal of Chiang Kai-shek statues, the renaming of places named after the former dictators, and the return of all assets the KMT obtained during the martial law period are thus part of their attempts to deal with the past.

Since most of the key perpetrators of the 2-28 Massacre and the White Terror were ethnic Han nationalists, the issue of national (ethnic) identity is bound to hijack the issue of transitional justice. The persistent military threat posed by the motherland of the Han nationalists has worsened the Taiwanese nationalists' perception of Han nationalism and Mainland China. As a consequence, calls for transitional justice have on several occasions degenerated into anti-China sentiment and calls for deSinofication. In the eyes of Han nationalists, de-Sinofication equals racial persecution. Since the early 1990s, leaders of the Taiwanese nationalist movement have thus frequently been branded 'fascists,' or compared with the world's most infamous (nonHan) dictators. Leaders and grassroots supporters of Han nationalism share the notion that the most evil of all Taiwanese 'fascist leaders' is none other than former President Chen Shui-bian. The judgement was first made in 1994, when Chen contested the mayoral election in Taipei. Rival candidate and influential Han nationalist leader Chao Shao-kang yelled at Chen during a live televised debate, calling him a fascist. Years later, the KMT compared Chen with Mussolini in an official televised electoral campaign commercial, and in 2004 the KMT-lead presidential election alliance urged the people of Taiwan in official campaign advertisements to oust "Taiwan's Adolf Hitler", Chen Shui-bian, from the presidency. 4

The perceived persecution of ethnic Han nationalists and the rise of Taiwan's "Adolf Hitler" became the most debated issue among Han nationalist scholars and grassroots supporters in the aftermath of the 2004 presidential election. Publications detailing the 'similarities' between the rise of Hitler and Chen Shui-bian mushroomed and were sold in bookstores throughout the island. One of the most popular publications at that time was Shuddering Future: Dismantle Taiwan's New Dictatorship, in which the author discusses in detail the rise of Taiwan's "Hitler" and urges readers to assist the new democracy movement in protecting democracy in Taiwan (Huang 2004). The front cover of the publication shows a silhouette of Chen Shui-bian and a modified DPP party emblem in the shape of a swastika. The book was endorsed by a large number of established intellectuals and civic-rights groups, such as the Democratic Action Alliance, which was founded in 2004 by a group of wellknown professors from Taiwan's elite universities.

In addition to the local discourse, the overseas Han nationalist community in the USA expressed their deep concern about the decay of democracy, the "persecution of Mainlanders," and the rise of Taiwanese nationalism. The Taiwan Civil Rights Watch Group based in Washington D.C., for example, concluded its 2004 report on human rights abuses in Taiwan with the assessment that, "Taiwan is well on its way toward a dictatorial holocaust" (Taiwan Civil Rights Watch Group 2004, 20).

Moreover, Han intellectuals see flaws in the Taiwanese nationalists' concept of transitional justice:

"What do they know about justice? Don't they support Japanese revisionism? How can they say they want justice, when they don't want to 
address the crimes their Japanese friends committed in Taiwan and other parts of the world?"

The almost deifying attitude toward Imperial Japan and Japanese right-wing intellectuals, such as that of writer Kobayashi Yoshinori, who denies the existence of the Nanjing Massacre and other crimes committed by the Japanese in the 1930s and 1940s, is a blind spot in the Taiwanese nationalists' concept of transitional justice, which has made it even more difficult for the DPP government to address transitional justice without risking their call for it becoming pure anti-Chinese sentiment. ${ }^{6}$

Moreover, given the fact that the DPP lacked a majority in parliament and the KMT still had substantial financial and social resources, Chen's attempt was ill fated from the beginning. During the first few months of his term, Chen tried to find a compromise by appointing a KMT member as premier. The cooperation proved to be fragile and the premier resigned ostensibly for health reasons after a few months in office. The resignation was widely seen as a result of the DPP-led government's attempt to halt the construction of the fourth nuclear power plant. The KMT was outraged about the DPP's actions, since the construction had already been approved by parliament. Chen's disregard of parliamentary decisions was viewed as a violation of the constitution and the KMT initiated a recall motion against President Chen in parliament. The motion failed, however, since the KMT and its allies did not have the required two-thirds majority in parliament. Notwithstanding, the incident marked the beginning of deepening antagonism between Han and Taiwanese nationalists. Consequently, Chen Shu-bian more and more became the personal target of Han nationalists. This antagonism also contributed to Han nationalist opposition to every single policy related to the enhancement of democracy.

Ma Ying-jeou's victory in the presidential election 2008 was praised by the international community as a major step towards peace and security in East Asia. Eight years earlier, the world had praised Chen Shui-bian's victory as a major step towards a consolidated democratic Taiwan. But Chen's call for transitional justice and his attempts to safeguard Taiwan's sovereignty as an independent state caused domestic and international uproar and shifted the world's view from the importance of democratic consolidation to the importance of regional security and business interests. Ma Ying-jeou's rapprochement with the People's Republic of China and his ability to converse in English earned him far more popularity with the international community than Chen Shui-bian's determination to turn Taiwan into Asia's most democratic state. Local and international human rights activists, on the other hand, predicted a democratic regression under the new pro-Beijing government. With the KMT's return to power, a number of policies adopted by the previous government were reversed, especially those dealing with transitional justice, which has seriously undermined the national reconciliation process. In addition, Ma's election victory brought back to power a number of conservative Han nationalists at key government positions, which led to a revival of several martial-law practices and institutions (see Political Institutions).

During the 2008 presidential election campaign, Ma Ying-jeou and his campaign team emphasized the importance of ethnic harmony and reconciliation. In his campaign book Spirit of Native Village: A Common Story of Taiwan, he nevertheless defends every aspect of the Han nationalist perception of justice. The book praises Han nationalist achievements, while attacking Japan for its refusal to take responsibility for its dark past. 
Moreover, Ma Ying-jeou's party chairmanship and presidency has been accompanied by a rise in Han nationalism and racist rhetoric. In September 2007, for example, the KMT sponsored an advertisement in Taiwan's leading newspapers urging the people to join a political event. ${ }^{7}$ The advertisement asked the people to wear "their whiteblue slippers." nationalist legislators had previously called ethnic Taiwanese government officials low class for wearing slippers at work while at the same time praising Mainlanders who wore leather shoes.

The Kuo Kuan-ying case is a further example illustrating the attitude of Han nationalists toward Taiwan and the Taiwanese. Kuo had worked for the government for twenty years and had held several high-ranking government positions before public protest forced the government to impeach him for writing a number of online articles ridiculing Taiwan and its people. The online articles referred to Taiwanese as "Taiwanese rednecks," and "Japanese pirates." Kuo also wrote in one blog entry that "the imposition of martial law had been a benevolent act of the then government" and that China "should spend many years suppressing [people in Taiwan] instead of granting any political freedom once it has taken Taiwan by force." In the same article Kuo considered himself a "high-class Mainlander." Unfortunately, Kuo is not the only senior government official who believes in the racial superiority of the Mainland Chinese and the inferiority of the Taiwanese. Despite the fact that Ma Ying-jeou promised ethnic harmony during his presidential campaign, he and his government failed to condemn Kuo's statement when the first media reports dealing with the case appeared. It was only because of public outrage that Kuo finally was removed from his government position and that the KMT government acknowledged that Kuo's statements had been "inappropriate."

A further problematic move was Ma Ying-jeou's decision to restore the original name of the Taiwan Democracy Memorial. Under Chen Shui-bian the Chiang Kaishek Memorial was renamed because the DPP government felt it wrong to commemorate a brutal dictator and to belittle the widespread and systematic human rights abuses committed by Chiang Kai-shek and the KMT. The Taiwan Democracy Memorial should have symbolised the Taiwanese struggle for democracy and should have made future generations aware of the past atrocities. By renaming the memorial, the KMT once more created a divided society, a country with two opposing value systems. On one side, there is the Chiang Kai-shek Memorial representing the perpetrators and their supporters. On the other side, there is the 2-28 Massacre Memorial Museum commemorating the suffering of the victims and their relatives.

The glorification of Chiang Ching-kuo reached a new momentum in March and April of this year, when Han nationalists commemorated Chiang's $100^{\text {th }}$ birthday. Newly elected Ma Ying-jeou and his government did not distance themselves from the dictator during the celebrations as to show respect to the victims of the Chiang's dictatorship. On the contrary, Ma and senior government officials publicly praised Chiang Ching-kuo as a great leader. Moreover, T-shirts, tea cups, postcards, stamps and other commemorative items featuring the former dictator became widely available at department stores and post offices throughout Taiwan.

In a more recent case, the Ministry of Economic Affairs released a cartoon promoting the signing of a trade agreement between Taiwan and Mainland China. The cartoon portrayed Hoklo-speaking Taiwanese, the largest ethnic group in Taiwan, as stupid, backward and ignorant, whereas another ethnic group, the Hakka, was illustrated as intelligent, hard-working and well-educated. The KMT government 
agreed to remove the cartoon after fierce public protest but did not distance itself from the advertisement and the conveyed message.

\subsection{Political Institutions}

Political institutions comprise those that are constitutionally mandated, such as the parliament and judiciary, and those outside the constitutional framework. The latter type consists of the media, the educational system, law-enforcement agencies, and similar institutions. These institutions were politicised during the authoritarian period and transformed into instruments of social control. Both of these types of institutions in Taiwan are relics of either the Hsinhai Revolution of 1911 or the Chinese Civil War. They were designed to work under a one-party KMT dictatorship rather than in a modern democracy. This is particularly true for those institutions mandated by the constitution. Since the lifting of martial law in 1987, there have been several constitutional amendments in the form of revisions of additional articles superseding the original ones. The original constitution itself has never been altered and thus still lays territorial claims to Mainland China, Tibet and Mongolia. The additional articles are applicable to what is termed "free area of the Republic of China," that is Taiwan and several smaller islands. The Han nationalists and their political wing, the KMT and its splinters, have never given up their belief that there is only one China and that Taiwan is part of it. Apart from the rather obscure territorial claims, the revisions have mostly been pork-barrel deals between the KMT and the DPP, the two largest parties. In total, the additional articles have been replaced on four occasions and revised three times. The first two revisions (1991 and 1992) substantially contributed to Taiwan's democratisation, since they paved the way for direct elections of all parliamentary members (National Assembly and Legislative Yuan) and the president. Subsequent amendments primarily dealt with the electoral system applied in parliamentary elections, the powers and impeachment of the president, and the abolition of the National Assembly (Hsieh 2001). Unlike the important 1992/1992 amendments, the later revisions did not pursue long-term democracy-building goals but were crafted to address to the short-lived political gains of their drafters. The lack of commitment to long-term democracy-building policies is also reflected in the fact that there has been a remarkable flip-flop in the arguments put forward to justify amendments. In 1997, for example, an amendment was drafted to increase the number of Legislative Yuan members from 161 to 225 for the stated purpose of better representing the people. As a matter of fact, however, the number was increased to accommodate unemployed provincial assembly members. (The 1997 revision also called for the dissolution of the provincial assembly.) Several years later, the same group of politicians justified the reduction of parliamentary members by making claims of overrepresentation in the Legislative Yuan.

A further serious problem of the amendment process is the fact that that there has been limited involvement by constitutional scholars. The revisions have mostly been the product of deals reached by politicians and thus tended to be counterproductive to Taiwan's long-term democratic development. The 1999 revision and its subsequent annulment by the constitutional court exemplify the lack of professionalism in the amendment drafting process (Constitutional Court Interpretation No. 499).

Moreover, the authoritarian KMT rule for over four decades brought about several misconceptions about the obligations of political institutions, which has contributed to a number of disputes and public distrust. For example, it is a common 
belief that the president has extensive powers and that he or she is the chief executive. Under the original constitution of 1947, the president is only the head of state. Apart from the figurehead role, he or she is expected to act as a mediator between parliament and government (Article 44). The original constitution vests few real powers of control into the presidency. A president, for example, cannot dissolve parliament. The president may only ask parliament to reconsider legislation, which it could uphold by a two-thirds majority. Chiang Kai-shek, however, extended his constitutional powers by promulgating the so-called Temporary Provisions, which superseded the Constitution. In addition, he applied extra-constitutional methods to take control over every single political, social and economic institution. The strong presidency under Chiang Kai-shek and his son led to public misconceptions about the constitutionally mandated powers of the president. In 1991, the Temporary Revisions were replaced by another set of regulations superseding the constitution, the so-called Additional Articles. If compared with the martial law era, the additional articles have considerable weakened the status of the president while at the same time granting the president more rights than stipulated in the original constitution. The revisions, for example, now allow the president to appoint a premier without parliamentary consent. This new constitutional arrangement fails to produce enough incentives to enter crossparty negations with the objective of forming coalition governments. Powerless minority governments, such as those during Chen Shui-bian's terms in office, are the result. Minority governments are confronted with the problem of not having enough legislative power to implement their policies. Other instruments, such as the president's right to veto legislation or to dissolve parliament, may assist minority governments in pushing through required legislation. The revisions, however, curtailed the presidential veto-power (vetoed legislation now only requires a majority vote to uphold it) and the president may now dissolve parliament but only upon a vote of no confidence in parliament.

Moreover, the post-martial law constitutional revisions neglected several important institutions, such as the Control Yuan. Under the constitution, the Control Yuan is the highest government body with the constitutional right to investigate wrongdoings of public officials (Article 90). In practice, this institution has had a rather limited impact on improving the democratic environment. On the contrary, it has on several occasions hindered the establishment of other investigative bodies, such as parliamentary committees of inquiry and a national human rights commission. Opposition to additional investigative bodies partly stems from the misconception that Control Yuan is the 'only' control organ of the State. Any other investigative body would thus per se violate the constitution.

Apart from constitutionally mandated institutions, there are others whose reform is of vital importance to the process of democratic consolidation in Taiwan. This set of institutions includes the media, the educational system, and law enforcement agencies. Each of these previously played an important role in the KMT's attempts to control society. Since the lifting of martial law, they have not fully adapted to the new, democratic environment.

Media: The number of media outlets has increased dramatically over the last two decades, but journalists and other media professionals have failed to understand their role in a democratic society. Media outlets have mostly been active in promoting sensationalism and political persecution. Journalists and political television personalities have contributed to the deterioration of serious public debate and undermined the authority of courts. Show-trial journalism as a relic of the martial law 
period has increased over the past few years. It is a common journalistic practice to pursue political opponents and criminal suspects to the point of mental breakdown, which usually constitutes a major part of news programmes. In several cases this practice has resulted in people subjected to such treatment committing suicide. Journalists and other media professionals tend to feel no regret over their conduct. On the contrary, there is the belief that it is the fundamental right of media professionals in a democratic society to report what people 'want to know,' no matter how inhumane their actions or what the consequences thereof may be. Two decades after the lifting of martial law, only few media professionals see a necessity to change current practices (Wang 2005).

During Chen Shui-bian's presidency, the DPP government tried to push through a thorough reform of the media, which should have improved the quality of news reporting (less sensationalism, more intellectual discourse) and decreased political control over it. Apart from the widespread misconceptions about the role of media professionals in a democracy, politicians from all political parties have been very influential in the agenda-setting process, which further contributes to a dysfunctional media environment. Politicians have been hosts of political talk shows, held management positions in media outlets, and have been stockholders in media companies. Chen's reform intended to ban politicians from exercising control over the media through these channels. The proposed media reform failed to materialize, however, after being met with considerable resistance and being interpreted as a means to persecute political opponents.

Judicial system: The primary function of the police in martial-law Taiwan was to preserve the authoritarian state. Laws were arbitrarily enforced. Close cooperation with organized crime gangs in exchange for favours, e.g. killing of political opponents, was common practice. Police in general refrained from interfering in 'private matters,' such as domestic violence or blackmail. Crime statistics were manipulated in various ways. For example, cases reported to the police were never official documented. Twenty years after the lifting of martial law, law enforcement still retains some of these characteristics. Cases of police officers refusing to investigate domestic violence, rape, sexual harassment, fraud and organized crime activities are still in evidence. There are also reports of mayors and county magistrates instructing law enforcement agencies to only accept cases that can easily be solved as to reduce crime rates and boost their personal popularity.

Educational system: During the martial law era, the educational system was designed to control students' thoughts and social activities. Teachers and military personnel played an important role in "guiding" the students and in helping them to "solve" problems. In their free time, students had to take part in social activities that were supervised by so-called military drillmasters (jiaojguan) and homeroom teachers (daoshi). Twenty years after the lifting of martial law, little has changed. There still are homeroom teachers and military officers present at high schools, colleges and universities.

As pointed out earlier, Ma's election victory brought back to power a number of conservative Han nationalists in key government positions, which led to a revival of several martial-law practices and institutions. The ministry of education, for example, has reversed the DPP policy of gradually phasing out military personnel at secondary schools and institutions of higher education. The previous government regarded the so-called military drillmasters a relic of the authoritarian period and tried to pass 
legislation removing all military personnel from schools, colleges, and universities. As the KMT blocked such legislation in parliament, the DPP government adopted the policy of not filling vacancies left by retired personnel. The number of drillmasters thus dropped from 1,627 to 1,058 during Chen's presidency. ${ }^{9}$

\subsection{Politics as popular culture and the authoritarian mindset}

In the past, the mass mobilisation of the electorate and the festive character of elections were characteristics usually found in literature on authoritarian countries with limited electoral processes (Hermet, Rose and Rouquié, 1978). More recently, a number of scholarly articles and other publications have highlighted the fact that politics has become part of local popular culture with elections turning into major social events in a number of former authoritarian countries since the advent of the Third Wave and its attendant political changes (Chua 2007, Strauss and O'Brien 2007). Taiwan is no exception here. After the lifting of martial law in 1987, political scientists frequently talked about an overpolitisation of Taiwan's society (Chao 1998). Political parties and other political institutions mushroomed. It seemed as if everyone wanted to have his or her own political party. Social and other problems were politicised and used by political actors to mobilise the masses. Political events were no longer entirely controlled by political power brokers. On the contrary, Taiwan entered the era of mass politics. Political actors, such as the KMT, had to adjust to the changing environment as to survive. Thus, soon after the lifting of martial law, a group of liberal intellectuals stressed the need for a modernization of the KMT through the application of modern political management concepts. One of the most outspoken supporters of such reforms was John Kuan, a senior party official. John Kuan described the changing political and social environment of the late 1980s with the following words:

During the past four decades, our society has undergone three major changes in development. In the 1950s and early 1960s, political forces predominated. From the 1960s on, economic forces had the upper hand. Now we are entering a third stage where social forces are predominant. People are better educated and more resourceful today. They are more concerned with social issues such as environmental protection, law enforcement, and public health measures. Moreover, they are ready to act if necessary to make their voices heard (Kuan 1992, 17).

Kuan compared the KMT with the US company Procter \& Gamble. Both 'companies,' he believed, harboured similarities. Both had a long history, the KMT a history of 94 years and P\&G one of 150 years, and both had developed a strong and vigorous entrepreneurial culture, "which perpetuates its functions and prosperity" (Kuan 1992, 49). He also noted that during the martial law period the party had enjoyed a virtual monopoly on political resources. The party had merely functioned as a mechanism for "the internal distribution of power," whereas "today the party is confronted with political competition" (Kuan 1992, 18). Kuan called for a sophistication of the KMT's entrepreneurship, that is the application of professional marketing techniques, as to cope with the changing environment: 
In this open, competitive, and market-conscious society, consumers can pick and choose among many commodities. Rational consumers will always choose those commodities that are of good quality with reasonable prices. We must not forget that we are entering the age of marketing. In a market-driven age, producers must take whatever measures are necessary to produce attractive commodities. Everywhere we turn today, we run into the "SP" acronym for sales promotion. For a political party, its platform and candidates can be considered products. Voters can be considered consumers. The question is how do we make our party platform and candidates attractive to the voters. In this age of enlightenment, voters know their personal preferences. They are autonomous and independent. Under these circumstances, our primary job is to design comprehensive plans for promoting and advertising our party platform and our candidates during non-election times as well as at election time (Kuan 1992, 15).

The application of modern political management techniques not only changed the relationship between the people and the political elite but also contributed to the rise of populism and a trivialization of politics. Within a few years, the new political paradigm affected all aspects of political communication. Political actors were increasingly engaged in event marketing. Well-known singers, entertainers and even strippers were invited to perform at political events in order to attract the masses and obtain popular support at the polls. Such events known as gewuxiu became very popular at the early 1990s (Huang and Chen 1991).

It was not long before this adoption of consumer-oriented politics sparked a serious debate about the perils of modern political management concepts. The perceived trivialization of politics was often the issue of critical debates among liberal and conservative intellectuals and was highlighted in the movie The Candidates by movie producer Hsu Li-kong. ${ }^{10}$ A number of established scholars, such as Wang Chen-huan and Chian Yong-hsiang, were concerned that the new political philosophy would undermine democratic institutions and eventually lead to a new dictatorship (Wang and Chian, 1995). Huang Kuang-guo (1995), professor of psychology at National Taiwan University, elaborated on Wang and Qian's observations in his popular book About Populism and the End of Taiwan. Huang asserted that most people misunderstood the true meaning of liberal democracy. In a liberal democracy, he argued, the government should protect the rights of the individuals. The rules and regulations concerning the question of how to protect those rights should be obtained through a democratic process. In his view, the government should guarantee the execution of those rules and regulations. Elections should only be part of the democratic process, not the ultimate goal. Huang believed that elections in Taiwan had come to be viewed as the core value of democracy, which he thought was a misconception that would finally lead to populist authoritarianism and the end of the rule of law and social justice. In his book, he cited several examples illustrating how commodification politics had already trivialized politics and cultivated mob rule. For these reasons, Huang and other conservative mainstream scholars favoured elite politics over popular politics, and were outspoken opponents of commodification politics.

Notwithstanding, contemporary Taiwanese politics has remained mass politics. Moreover, it has become part of popular culture. Politics has to be entertaining. It has to be a drama, a soap opera (Schafferer 2006). 
But more worrisome than the commodification of politics is the prevailing authoritarian mindset that exists in elite Han nationalist circles. The conflict between the Chinese and Taiwanese nationalists is more than just a question of national identity and restorative justice. It is a struggle between conservative power brokers who favour elite politics and liberal intellectuals who consider mass politics as an indispensable part of a modern democratic society. The first group predominantly consists of first and second generation Mainlanders, whereas the latter comprises Taiwanese intellectuals who actively participated in the democracy movements of the late 1970 s and early 1990 s.

During the last eight years the conflict over the modus operandi of political institutions has intensified with conservative Han nationalists eventually gaining the upper hand. Chen's presidency was overshadowed by a number of cases that strongly illustrate the struggle between the two different mindsets.

Human rights commission: In his inaugural speech in May 2000, Chen Shui-bian made clear his intention to transform Taiwan into Asia's most democratic state. He promised to establish an independent national human rights commission and to codify two international human rights covenants (UN convents on Civil and Political Rights and Economic, Social and Cultural Rights) into national legislation. Subsequently, a human rights advisory council was set up at the presidential office and several international organisations, such as Amnesty International and the International Commission of Jurists, were invited to assist the president in formulating and implementing his policies. The codification of international humanitarian laws into national legislation was blocked in parliament by the KMT. The DPP government asked for legislative approval of the two above-mentioned UN convents during the fourth, the fifth, and the sixth terms of the legislature in 2001, 2002 and 2005. Draft statutes of a national human rights commission based on the Paris Principles were submitted to parliament several times, but each time encountered strong opposition from KMT parliamentarians. They did not see the need for such a commission and mainly argued that the Control Yuan as the 'sole' investigative body was responsible for investigating human rights abuses. Neither the Constitution nor the Control Yuan statutes, however, explicitly mandates the Control Yuan to investigate human rights abuses. Moreover, the Constitution itself only mandates that the Control Yuan "shall be the highest control body of the State and shall exercise the powers of impeachment, censure and audit." It does not define the Control Yuan as the sole investigative body of the State and thus does not rule out the establishment of other organs, such as parliamentary committees of inquiry.

Referendum law: Despite the fact that the Constitution grants people the right of political participation through referenda and that it stipulates that such participation be regulated by law (Article 136), the KMT had for over 50 years blocked any attempt to pass referendum law legislation. In 2003, the KMT presidential candidate first described calls for a referendum law as "nonsense," but soon changed his opinion after Chen Shui-bian turned it into a salient campaign issue and there was strong public support for it. The KMT subsequently passed a referendum law and successfully presented itself as a strong supporter of democratic institutions, whereas images of proud KMT parliamentarians holding banners with anti-referendum slogans had covered TV screens and newspaper front pages several months earlier.

Transitional justice: In 2007, the DPP government made public its plan to hold a referendum concurrently with the scheduled parliamentary elections in 2008. The referendum asked the people whether there should be legislation to deal with the KMT's property (illegally) obtained during the martial law era. Since the KMT- 
controlled parliament had previously refused to negotiate or consider legislation dealing with the issue, Chen Shui-bian and the DPP respectively saw in the referendum an opportunity to raise public awareness and to assert pressure on the KMT. Apart from that, the referendum served as a strategically important campaign tool. The Han nationalists saw in the referendum an attempt to persecute their leaders and retaliated by initiating a referendum requesting the punishment of "national leaders" for "causing harm to the nation:"

Do you agree on the establishment of legislation holding the national leaders and subordinates legally responsible for causing harm to the nation, deliberately or through major error; that any investigation be conducted by legislative investigative committee; and that government departments must cooperate and may not refuse to do so, all in the public interest, and that those who break the law or are derelict in their duties of office be punished and required to return any improperly obtained income? (Referendum, 23 March 2008)

The motives behind the referendum are highly questionable for several reasons. The Han nationalists, for example, had a majority in parliament and could thus have passed such legislation without a referendum. Moreover, the proposed legislation would infringe upon the rights of the judiciary. A parliamentary committee of inquiry should be an institution determining political rather than legal responsibility. The creation of a supra-judicial body outside the constitutional framework violates constitutional concepts and the basic principles of democratic rule.

Truth commission: The proposed referendum requesting the punishment of "national leaders" for "causing harm to the nation" was, in fact, the second time during the Chen presidency that the Han nationalists tried to use supra-judicial bodies to persecute political opponents. The first attempt was made after the 2004 presidential election defeat, when the KMT and its allies pushed through legislation to establish a truth commission, which was to investigate whether Chen Shui-bian masterminded the failed assassination attempt on his life to attract votes. With the commission, the KMT created an institution that replaced the judiciary. It was granted investigative powers that exceeded even those of state prosecutors. In addition, the statutes of the commission allowed retrials of any related court case the commissioners deemed to be a miscarriage of justice. Moreover, the establishment of the truth commission was a hypocritical act since its founders had previously claimed that it would be unconstitutional to form any investigative body, such as the national human rights commission proposed by Chen Shui-bian, outside of the Control Yuan. Critics of the truth commission questioned its legality and wondered whether the KMT had previously fooled the people with its claim that the Control Yuan was the sole legal investigative body. Consequently, DPP parliamentarians asked the Constitutional Court for an interpretation. In its interpretation, the court rejected the Han nationalists' claim that any investigative body outside the Control Yuan would be unconstitutional per se (Constitutional Court Interpretation No. 585). Although the establishment of the truth commission itself was not deemed unconstitutional, several of its provisions were. The court ruled that the statutes circumscribed the authority of other constitutional organs, such as the judiciary, and thus violated basic principles of constitutional democracy.

Separation of power: The Han nationalist campaign against Chen and the DPP in the aftermath of the "stolen" 2004 presidential election brought about several other 
highly questionable actions, which undermined the rule of law and seriously endangered basic principles of democratic rule, such as the separation of powers. The judiciary, for example, was punished for not delivering the right verdict in the KMT-sponsored lawsuit demanding the annulment of the 2004 presidential election. Han nationalist legislators retaliated by cutting the financial benefits of the involved judges in a parliamentary budget-screening session. The legislators commented on their action with the statement that the judges had obviously not done a good job and thus did not deserve the taxpayers' money. Despite the fact that the Constitutional Court (Interpretation No. 601) subsequently ruled the legislators' action as unconstitutional, the involved legislators defended their action as being fully justified. A further example is the attempt to recall parliament members who opposed the Han nationalist motion to impeach President Chen. After losing the 2004 presidential election, the KMT and its allies tried several times to initiate impeachment proceedings against Chen, but failed each time because the required two-thirds majority could not be obtained. Han nationalists exerted pressure on DPP parliamentarians to support the impeachment motion in parliament. The DPP parliamentarians did not accede, however, and Han nationalist legislators subsequently asked their supporters to collect signatures to recall the 'traitors.'

In a more recent case, two senior KMT legislators forced their way into the campaign headquarters of DPP presidential hopeful Frank Hsieh. They trespassed on private property on the pretext that as legislators they had the right to investigate whether Hsieh had illegally used office space on the upper floors of the building.

\section{Conclusion}

As pointed out at the beginning of this paper, in political science there is broad interest in whether a newly established democracy succeeds in overcoming the perils of democratisation and matures into a consolidated democracy or regresses to authoritarianism. Taiwan's transition to democracy began in the late 1970s and since then it has experienced a number of socio-political 'crises.' I argue that these 'crises' have predominately been the result of historical legacies. The future of Taiwan's democratic consolidation, therefore, is primarily a question of how to overcome these legacies. In this paper, I outlined three different dimensions of democratic consolidation. Each dimension consists of a different set of historical legacies. Ethnic and national identity constitute the first set. The second one comprises political institutions and institutionalised processes that were used during authoritarian rule to control society and have not yet adopted themselves to the new, democratic environment. The third set of historical legacies has to do with the authoritarian mindset that still exists in elitist political circles and the shift in political management concepts that have contributed to the rise of populism and trivialised politics.

Despite the fact that all three sets of historical legacies deal with different political domains, their origins and future development are closely linked to the issue of ethnic and national identity. Ethnic and national identity, on the other hand, are not the key to further democratic consolidation. The future of Taiwan's political development depends on how seriously the issue of restorative justice is dealt with by the political elite. From this perspective, Taiwan's process of democratic consolidation differs significantly from other democracies of the Third Wave and thus requires different policies to prevent a regression to authoritarian rule. 


\section{References}

Peng, Ming-min. 1972. A Taste of Freedom. New York: Holt, Rinehart and Winston.

Windrow, Hayden. 2005. From State to Nation: The Forging of the Han Through Language Policy in PRC and Taiwan. International Law and Politics. 37: 373422.

Chao, Yung-mao. 1998. Taiwan di fang zheng zhi de bian qian yu te zhi [Changes in Taiwan local politics]. Taipei: Han Lu.

Chen, Hong-tu. 2006. History of Taiwan [taiwan shi]. Taipei: Sanmin.

Chen, Wen-chian. 2004. Simply afraid of Chen Wen-chian. Taipei: INK.

Chua, Beng Huat (ed.). 2007. Elections as popular culture in Asia. London; New York: Routledge.

Diamond, Larry. 2008. 'The Democratic Rollback: The Resurgence of the Predatory State.' Foreign Affairs, vol. 187, no. 2 (March/April): 36-48.

Fukuyama, Francis. 1992. The end of history and the last man. New York: Free Press. Hermet, Guy, Richard Rose and Alain Rouquié (eds.). 1978. Elections without choice. London; New York: Macmillan.

Hsieh, Cheng-tao. 2001. The History of Revisions to the ROC Constitution [zhonghuaminguo xiuxianshi]. Taipei: Polis.

Huang, Chia-shu and Rui Cheng. 1991. Taiwan zhengzhi yu xuanju wenhua [Taiwan Politics and Election Culture]. Taipei: Boy Young.

Huang Kuang-guo. 1995. Mincuiwangtailun [About Populism and the End of Taiwan]. Taipei: Shangchou.

Huntington, Samuel P. 1991. The third wave: democratization in the late twentieth century. Norman: University of Oklahoma Press.

Kuan, John. 1992. The Modernisation of the Kuomintang: Observations and Expectations. Taipei: Democracy Foundation.

Lee, Teng-hui. 2004. Witnessing Taiwan: President Chiang Ching-kuo and Me [jianzheng taiwan: jiang jingguo zongtong yu wo]. Taipei: Yunchen.

Lin, Hsin-ho. 1986. Der völkerrechtliche Status der Republik China (Taiwan) nach dem Ausschluss der nationalchinesischen Regierung aus den Vereinten Nationen: Dargestellt im Licht der internationalen Praxis. Ebelsbach: Verlag Rolf Gremer.

Lin, Yao-song. 2004. Li deng hui yu guomindang fenlei [The Broken Relationship between Lee Teng-hui and the KMT] Taipei: Haixiaxueshu.

Linz, Juan and Alfred Stepan. 1997. Toward Consolidated Democracies. In Larry Diamond, Marc F. Plattner, Yun-han Chu, and Hung-mao Tien, eds. Consolidating the Third Wave Democracies. Baltimore: The Johns Hopkins University Press.

Huang, Zhi-xian. 2004. Shuddering Future: Dismantle Taiwan's New Dictatorship [zhanli de weilai: jiegou taiwan xin ducai], revised edition. Taipei: Miluo.

Schafferer, Christian (ed.). 2006. Election Campaigning in East and Southeast Asia, Aldershot: Ashgate

Strauss, Julia C and Donal Cruise O'Brien (eds.). 2007. Staging Politics: Power and Performance in Asia and Africa. London: I. B. Tauris.

Taiwan Civil Rights Watch Group. 2004 Taiwan's Civil Rights Violation Report. Washington DC: Democracy and Truth Alliance.

Thompson, Mark R. 2008. 'From Democratic Revolutions to Uncivil Society in Asia: Asian Democracy between Consolidation and Crisis.' Prospects of Democracy in East Asia for the $21^{\text {st }}$ Century: Issues, Threats, and Challenges, workshop 
organized by the Asian Political and International Studies Association, Jakarta, November 28-29.

Quimpo, Nathan Gilbert. 2008. 'Asian Democracy between Consolidation and Crisis.' Prospects of Democracy in East Asia for the $21^{\text {st }}$ Century: Issues, Threats, and Challenges, workshop organized by the Asian Political and International Studies Association, Jakarta, November 28-29.

Wang, Chen-huan and Yong-hsiang Chian. 1995. 'Yuxiang xinguojia? Mincuiweiquan zhuyi de xingcheng yu minzhuwenti' [March Towards a New Nation State? The Rise of Populist Authoritarianism in Taiwan and its Implication for Democracy]. Taiwan: A Radical Quarterly in Social Studies 20 (August): 17-55.

Wang, Tien-bin. 2005. Freedom of the Press [xinwen ziyou]. Taipei: Asia-Pacific Press

Zhou, Yu-kou. 1993. Li denghui de yiqiantian [Lee Teng-hui's first thousand days in office] Taipei: Mai-tian.

\section{Notes}

Interview with senior official, Ministry of Interior Affairs, Taipei, May 2007.

Interview with senior representative, Compensation Foundation for Improper Verdicts, June 2007.

Interview with senior KMT official, April 2007.

A scan of the advertisement can be viewed at http://www.eastasia.at/vol3_1/ad1.htm.

Interview with senior KMT party official, June 2007.

6 For a detailed account on the close relationship between Taiwanese nationalists and Japanese revisionists see Phil Deans, "Taiwan in the Japanese Nationalist Imagination: The Positive Other," paper presented at the International Convention of Asia Scholars 5, Malaysia Convention Centre, Kuala Lumpur, 2-5 August.

7 China Times, 15 September 2007, A1.

8 The featured slippers are very popular in Taiwan, especially in the South.

9 Interview with former senior official, Ministry of Education, November 2008.

10 For more on the DPP's response: Christian Schafferer, "Electoral Campaigning in Taiwan," in Election Campaigning in East and Southeast Asia, ed. Christian Schafferer (Aldershot: Ashgate, 2006), 46-7. 